\title{
Kajian Kapasitas Tampungan Penyimpanan Air di Catchment Area Danau Sipin
}

\author{
Azwarman \\ Dosen Fakultas Teknik Universitas Batanghari Jambi \\ Correspondence email: warman2789@gmail.com
}

\begin{abstract}
Abstrak. Keberadaan Danau Sipin sangat penting sebagai penampung air hujan yang berada di Catchment Area danau Sipin khususnya Kota Jambi. Posisi Letak danau Sipin tepatnya di wilayah Kec.Telanaipura Kecamatan Danau Sipin. Kalau dilahat dari atas atau dari udara Danau Sipin ini berbentuk seperti tapal kuda (oxbow Lake) dengan luas \pm 114 Ha. Sumber air yang masuk ke Danau Sipin terdiri dari Sei Kambang, Sei.Putri, Sei.Buluran Kenali, serta luapan Sei.Batanghari di musim banjir. Pemerintah daerah sedang giat giatnya membangun pengendalian banjir danau Sipin dengan dibangunnya beberapa pintu air yang bagus dan permanen yang terbuat dari struktur beton dan baja. Catchment Area Danau Sipin lebih kurang 11.749.320,6 m².Pemanfaatan Danau ini sangat besar selain sebagai penangkap banjir dengan menampung beberapa aliran sungai seperti tersebut di atas , juga dipakai sebagai tempat rekreasi masyarakat Kota Jambi.
\end{abstract}

Kata Kunci: Intensitas Hujan , Topografi ,Cathment Area, Debit Aliran Sungai

\section{PENDAHULUAN}

Danau adalah cekungan besar di permukaan bumi yang di genangi air yang pada umumnya air tawar. Indonesia merupakan negara yang mempunyai banyak sumber daya alam, salah satunya adalah sumber daya air. Cuaca Indonesia sangat mendukung untuk kesuburan alam, terutama hutan dan tanaman tumbuh dengan subur karena tersediannya sumber daya air. Daerah aliran sungai (DAS) harus dijaga dengan baik, luas dan volume tampungan (alami maupun buatan) harus diperhatikan, cuaca dan iklim, serta aspek pengelolaan sumber daya air oleh manusia itu sendiri.

Air perlu dipandang sebagai barang ekonomis tanpa harus melepas fungsi sosialnya. Sumber daya air juga merupakan kemampuan dan kapasitas potensi air yang dapat dimanfaatkan oleh kegiatan manusia untuk kegiatan sosial ekonomi. Terdapat berbagai jenis sumber air yang umumnya dimanfaatkan oleh masyarakat, sepeti air laut, air hujan, air tanah, air permukaan. Dari keempat jenis air tersebut, sejauh ini air permukaan seperti sungai, empang, danau, merupakan sumber air tawar yang terbesar di gunakan oleh masyarakat.

Danau Sipin merupakan suatu air yang tergenang menempati suatu cekungan yang ada di Kota Jambi. Danau Sipin terletak di Wilayah Kecamatan Telanaipura dan Kecamatan Danau Sipin. Danau Sipin juga disebut danau tapal kuda (oxbow lake).

Pada dasarnya danau memiliki dua fungsi utama, yaitu fungsi ekologi dan fungsi sosial-ekonomi-budaya. Fungsi ekologi danau adalah sebagai pengatur tata air, pengendali banjir, habitat hidupan liar atau spesies yang melindungi atau endemik serta penambat sedimen, unsur hara dan bahan pencemaran. Fungsi sosial-ekonomi-budaya danau adalah memenuhi keperluan hidup manusia.

Dalam rangka pemanfaatan air yang efisien untuk memenuhi berbagai kebutuhan, maka dilakukan kajian kapasitas tampungan penyimpanan air di catchment area Danau Sipin, Penelitian ini bertujuan untuk mengetahui kapasitas tampungan danau Sipin untuk menyimpan air berdasarkan kondisi topografi, dan air air itu bersumber dari mana saja dan berapa luas Catchment Area danau Sipin tersebut dan pemanfaatannya untuk apa saja .

Danau apabila perairan yang terbentuk dari cekungan bumi dengan tepi yang umumnya curam. Air danau bersifat jernih dan keberadaan tumbuhan air terbatas hanya pada daerah pinggir saja. Berdasarkan pada proses terjadinya danau dikenal danau tektonik yang terjadi akibat gempa dan danau vulkanik yang terjadi akibat aktivitas gunung berapi (Barus, 2004). Menurut Odum (1994) pada dasarnya proses terjadinya danau dapat dikelompokkan menjadi dua yaitu danau alami dan danau buatan. Danau alami merupakan danau yang terbentuk sebagai akibat dari kegiatan alamiah, misalnya bencana alam, kegiatan tektonik dan kegiatan vulkanik.

\section{Perairan Danau Oxbow}

Sihotang (2006) menyatakan bahwa oxbow adalah bagian dari aliran sungai yang alirannya terputus baik secara permanen atau sementara dari sungai aslinya dan terjadi secara alami ataupun buatan, pada skala waktu dapat terbentuk, kemudian habis selama beberapa tahun, tergantung pada tingginya banjir. 


\section{Daerah Tangkapan Air}

Daerah Aliran Sungai (DAS) adalah suatu wilayah daratan yang secara topografi dibatasi oleh punggungpunggung gunung yang menampung dan menyimpan air hujan yang kemudian menyalurkannya melalui sung ai utama.

\section{Presipitasi (Hujan)}

Faktor utama penyebab besarnya debit sungai adalah hujan, intensitas hujan, luas daerah hujan dan lama waktu hujan. Intensitas hujan berubah dengan lama waktu hujannya. Semakin lama waktu hujannya, semakin berkurang deras rata- rata hujannya.

\section{Mencari rerata curah hujan}

Metode Rata-Rata Aljabar

Persamaan yang digunakan :

$\operatorname{Pr}=\frac{\mathrm{P} 1+\mathrm{P} 2+\mathrm{P} 3+\mathrm{P} 4+\ldots .}{\mathrm{n}}$

\section{Metode Polygon Thiessen}

Perhitungan menggunakan rumus sebagai berikut:

$\operatorname{Pr}=\frac{(\mathrm{P} 1 \times \mathrm{A} 1)+(\mathrm{P} 2 \times \mathrm{A} 2)+(\mathrm{P} 3 \times \mathrm{A} 3)+\cdots(\mathrm{Pn} \mathrm{X} \mathrm{An})}{\text { A total }}$

$\mathrm{A}_{1}, \mathrm{~A}_{2}, \ldots \mathrm{A}_{\mathrm{n}} \quad=$ Luas daerah pada polygon $1,2, \ldots, \mathrm{n}\left(\mathrm{km}^{2}\right)$

Metode Isohyet

Perhitungan menggunakan persamaan sebagai berikut:

$P=\left(\frac{A 1}{\text { Atotal }} \times \frac{(P 1+P 2)}{2}\right)+\left(\frac{A 2}{\text { Atotal }} \times \frac{(P 2+P 3}{2}\right)+\left(\frac{A n}{\text { Atotal }} x \frac{(P n+P n+1)}{2}\right)$

Persamaan matematis yang di gunakan:

$\mathrm{Hh}=\frac{\frac{\mathrm{H} 1}{\mathrm{~L}^{2}}+\frac{\mathrm{H} 2}{\mathrm{~L}^{2}}+\ldots+\frac{\mathrm{Hn}}{\mathrm{Ln}^{2}}}{\frac{1}{\mathrm{~L}^{2}}+\frac{1}{\mathrm{~L}^{2}}+\ldots+\frac{1}{\mathrm{Ln}^{2}}}$

\section{Analisa Frekuensi Curah Hujan}

Untuk menghitung debit banjir dengan periode ulang tertentu, dipakai formula:

a. Metode Normal

b. Metode Log Normal

c. Metode Log Person III

d. Metode Gumbel

\section{Metode Normal}

Data curah hujan disusun dari urutan yang terbesar sampai yang terkecil.Distribusi normal atau kurva normal disebut juga distribusi Gauss. Probability density function (PDF) distribusi normal dapat dituliskan dalam bentuk ratarata dan simpangan bakunya, sebagai berikut:

$P(X)=\frac{1}{\sqrt{2 \pi}} \exp \left[-\frac{(x-\mu)^{2}}{2 \sigma^{2}}\right]-\infty \leq x \leq \infty$

Dalam pemakaian praktis, umumnya rumus tersebut tidak digunakan secara langsung karena telah dibuat tabel untuk keperluan perhitungan, dan juga dapat didekati dengan:

$\mathrm{K}_{\mathrm{T}}=\frac{\mathrm{x}_{\mathrm{T}}-\overline{\mathrm{X}}}{\mathrm{S}}$

Dimana:

$\mathrm{K}_{\mathrm{T}}=$ Faktor frekuensi (nilai variable reduced Gauss).

\section{Metode Log Normal}

Dalam distribusi Log Normal data $X$ diubah kedalam bentuk logaritma $Y=\log X$. Jika variabel acak $Y=\log X$ terdistribusi secara normal, maka X dikatakan mengikuti distribusi Log Normal. PDF untuk distribusi Log Normal dapat ditulis dalam bentuk rata-rata dan simpangan bakunya, sebagai berikut:

$P(X)=\frac{1}{X \sigma \sqrt{2 \pi}} \operatorname{esp}\left[-\frac{(Y-\mu Y)^{2}}{2 \sigma Y^{2}}\right] X>0$ 
$\mathrm{K}_{\mathrm{T}}=$ Faktor frekuensi, merupakan fungsi dari peluang atau periode ulang.

\section{Metode Log Person III}

$\mathrm{S}=\sqrt{\left[\frac{\sum_{\mathrm{i}=1}^{\mathrm{n}}(\log \mathrm{Xi}-\log \overline{\mathrm{X}})^{2}}{\mathrm{n}-1}\right]^{2}}$

a. Hitung koefisien kemencengan:

$$
G=\frac{n \sum_{i=1}^{n}(\log X i-\log \bar{X})^{3}}{(n-1)(n-2) s^{3}}
$$

b. Hitung logaritma hujan atau banjir dengan periode ulang $\mathrm{T}$ dengan rumus:

$$
\log \mathrm{X}_{\mathrm{T}}=\log \overline{\mathrm{X}}+\mathrm{K} . \mathrm{s}
$$

3.6.2 Metode Gumbel

$\mathrm{X}=\overline{\mathrm{X}}+\mathrm{S}$

\section{Intensitas Curah Hujan}

Monobe, dimana persamaannya adalah sebagai berikut:

$I=\frac{R_{24}}{24}\left(\frac{24}{t}\right)^{\frac{2}{3}}$

\subsubsection{Debit Rencana}

Metode Rasional sebagai berikut:

$\mathrm{Q}_{\mathrm{P}}=0,278 \times \mathrm{C} \times \mathrm{I} \times \mathrm{A}$

\section{Waktu Konsentrasi}

Perhitungan waktu konsentrasi dikembangkan oleh Kirpich (1940) yang ditulis sebagai berikut:

$\mathrm{t}_{\mathrm{c}}=\left(\frac{0,87 \mathrm{xL}^{2}}{100 \mathrm{xS}}\right)^{0,385}$

\section{METODE}

Metodologi penelitian dilakukan dengan survei lansung ke lokasi penelitian di Danau Sipin Kec.Telanaipura Jambi. Dalam menganalisa kemungkinan -kemungkinan yang termudah untuk mengambil pengukuran di pinggiran danau dan pengukuran kedalam danau dengan menggunakan naik perahu. Terlebih dahulu tentu disiapkan peralatan yang akan dibawa dan peralatan dokumentasi dan perekapan data.

Daerah atau lokasi penelitian seperti gambar dibawah ini:

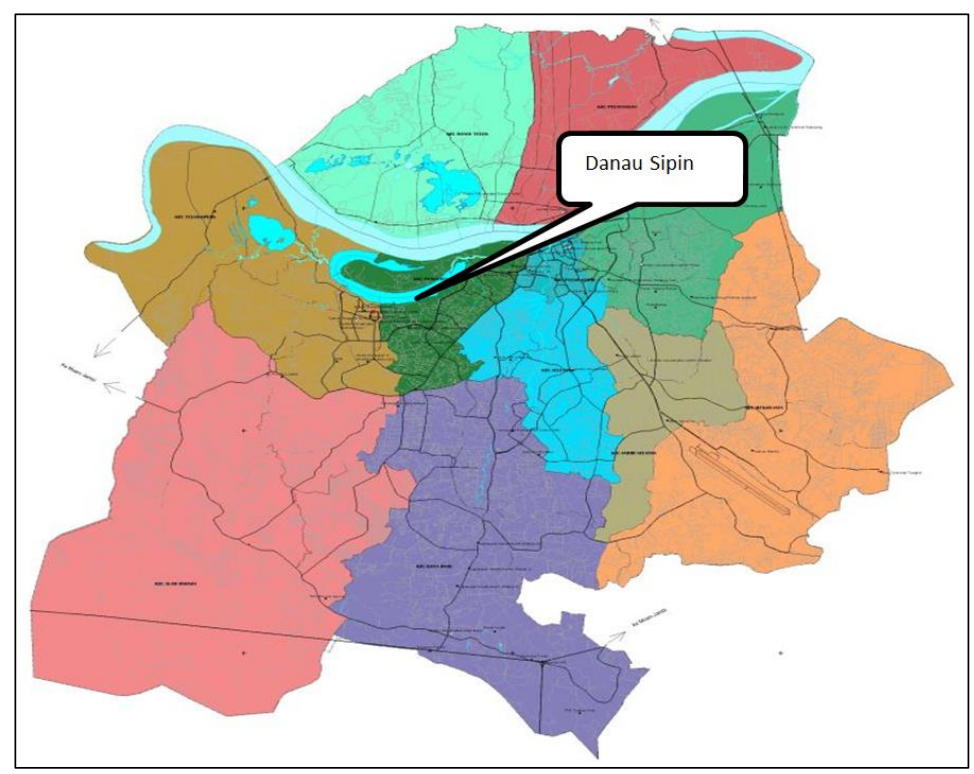

Sumber: Peta Administrasi Kota Jambi

Gambar 1. Peta Daerah Danau Sipin Kec.Telanaipura Jambi

Selain survei langsung, data sekunder yang digunakan dalam proses analisa tampungan Catchment Area Danau Sipin ini diperoleh dari beberapa pihak terkait. 
Penelitian dilakukan pada bulan Agustus - September 2019. Pengukuran permukaan dilakukan dengan cara mengelilingi danau dengan menggunakan alat Global Positioning System (GPS). Pengukuran bawah permukaan dilakukan dengan cara mengukur kedalaman dengan reng kayu yang sudah ditulis meterannya, dan perahu kecil. Pengambilan sampel kedalaman dan sampel lebar dan sample panjang danau dilakukan hanya beberapa sampel, karena dianggap peneliti sudah mewakili seluruh perairan Danau Sipin.

HASIL DAN PEMBAHASAN

Analisa Curah Hujan Harian Maksimum

Tabel 1. Data Curah Hujan

\begin{tabular}{|c|c|c|c|c|c|c|c|c|c|c|c|c|c|}
\hline \multirow{2}{*}{ No. } & \multirow{2}{*}{ Tahun } & \multicolumn{12}{|c|}{ Bulan (mm) } \\
\hline & & Jan & Feb & Mar & Apr & Mei & Jun & Jul & Ags & Sep & Okt & Nov & Des \\
\hline 1 & 2008 & 185 & 98 & 331 & 258 & 82 & 27 & 69 & 245 & 104 & 202 & 304 & 322 \\
\hline 2 & 2009 & 117 & 342 & 194 & 178 & 122 & 117 & 60 & 155 & 163 & 171 & 345 & 334 \\
\hline 3 & 2010 & 112 & 290 & 204 & 220 & 279 & 168 & 389 & 346 & 262 & 373 & 334 & 230 \\
\hline 4 & 2011 & 323 & 164 & 227 & 268 & 279 & 86 & 146 & 30 & 36 & 248 & 286 & 212 \\
\hline 5 & 2012 & 136 & 143 & 222 & 244 & 266 & 53 & 108 & 55 & 53 & 277 & 150 & 223 \\
\hline 6 & 2013 & 150 & 177 & 326 & 125 & 183 & 83 & 209 & 73 & 235 & 325 & 171 & 291 \\
\hline 7 & 2014 & 92 & 26 & 101 & 338 & 109 & 102 & 195 & 185 & 67 & 101 & 228 & 238 \\
\hline 8 & 2015 & 158 & 111 & 178 & 304 & 134 & 35 & 73 & 37 & 0 & 36 & 354 & 298 \\
\hline 9 & 2016 & 104 & 195 & 70 & 234 & 80 & 76 & 127 & 199 & 109 & 130 & 209 & 140 \\
\hline 10 & 2017 & 129 & 191 & 196 & 298 & 158 & 233 & 55 & 68 & 216 & 230 & 340 & 273 \\
\hline
\end{tabular}

Sumber: Badan Meteorologi, Klimatologi dan Geofisika (BMKG), 2019

Tabel 2. Rekapitulasi Analisa Curah Hujan Maksimum

\begin{tabular}{cccccc}
\hline No & $\begin{array}{c}\text { Periode ulang (T) } \\
\text { Tahun }\end{array}$ & Normal & Log Normal & Log Person III & Gumbel \\
\hline 1 & 2 & 325,700 & 322,932 & $\mathbf{3 3 3 , 3 7 8}$ & 319,937 \\
2 & 5 & 361,505 & 363,776 & $\mathbf{3 6 3 , 2 7 7}$ & 370,816 \\
3 & 10 & 380,260 & 387,192 & $\mathbf{3 7 4 , 1 8 0}$ & 404,505 \\
4 & 20 & 395,605 & 407,467 & $\mathbf{3 7 9 , 7 8 1}$ & 436,816 \\
5 & 50 & 413,081 & 431,855 & $\mathbf{3 8 6 , 5 0 3}$ & 478,642 \\
6 & 100 & 425,017 & 449,344 & $\mathbf{3 8 9 , 1 3 7}$ & 509,988 \\
\hline
\end{tabular}

Sumber: Hasil perhitungan, 2019

Dan selanjutnya hasil analisis curah hujan dengan priode ulang dapat dilihat pada grafik berikut:

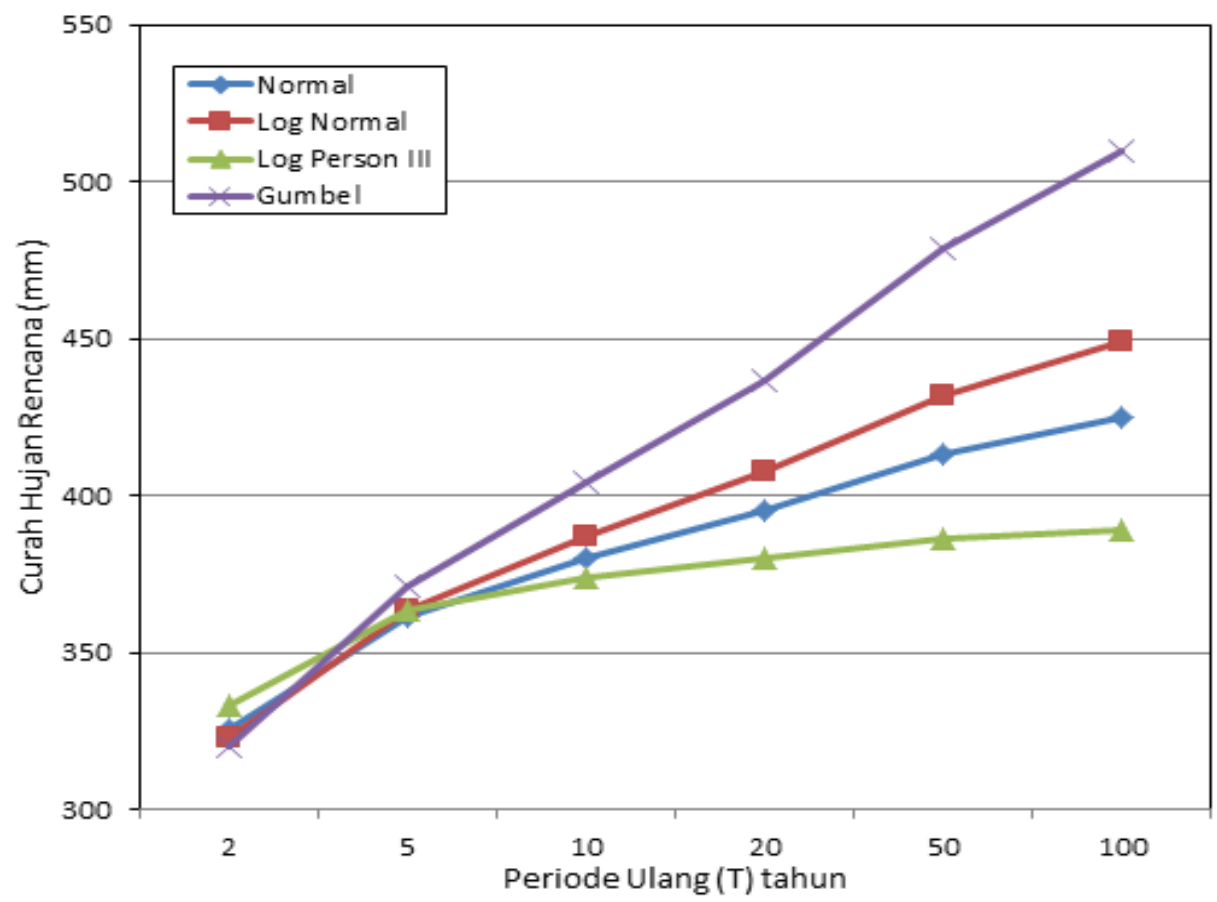

Sumber : Hasil olahan, 2019

Gambar 2. Grafik Curah Hujan Maksimum dan Periode Ulang 


\section{Daerah Tangkapan Hujan (Catchment Area)}

Daerah tangkapan hujan (Catchment area) adalah suatu area atau daerah tangkapan hujan dimana batas wilayah tangkapannya ditentukan dari titik-titik elevasi tertinggi sehingga akhirnya merupakan polygon tertutup, yang mana polanya disesuaikan dengan kondisi topografi, dengan mengikuti aliran air. Aliran air tersebut tidak hanya berupa air permukaan yang mengalir didalam alur sungai, tetapi termasuk juga aliran dilereng-lereng bukit yang mengalir menuju alur sungai sehingga daerah tersebut dinamakan daerah aliran sungai.

Pada lokasi penelitian, peneliti menentukan daerah tangkapan hujan (catchment area) menggunakan peta topografi Kota Jambi untuk menentukan luasannya. Luasan pada daerah tangkapan hujan (catchment area) hasil pengukuran adalah $11.749 .320 \mathrm{~m}^{2}$.

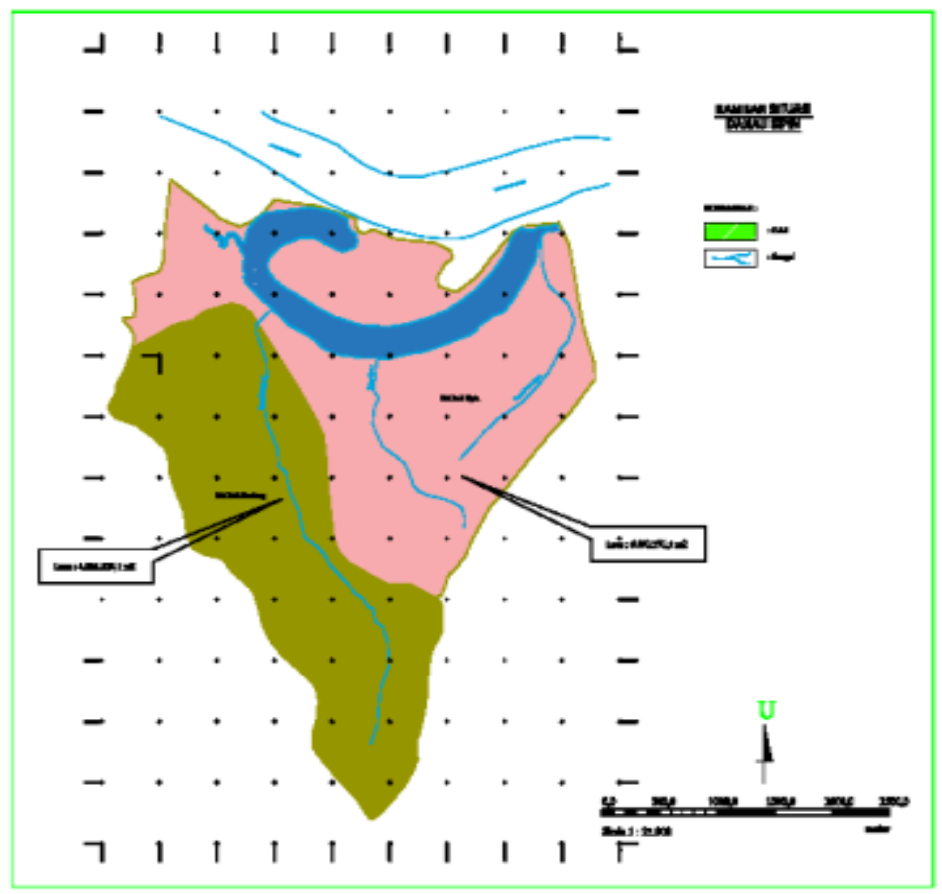

Sumber : Data olahan, 2019

Gambar 3. Peta Catchment Area

Berdasarkan data yang diperoleh, luas Peta Catchment Area Danau Sipin $\pm 6.892 .791,1 \mathrm{~m}^{2}$ Peta pada wilayah dataran Sungai Kambang $+4.856 .529,1 \mathrm{~m}^{2}$ Peta pada wilayah daratan Sungai Putri Total area daratan pada 2 wilayah $\pm \mathbf{1 1 . 7 4 9 . 3 2 0 , 6} \mathrm{m}^{2}$.

Dengan Luas area $\pm 11.749 .320,6 \mathrm{~m} 2$, dengan lengkungan Cathment Area seperti tapal kuda yang tergambar pada Kontur Topografi Danau Sipin dibawah ini.

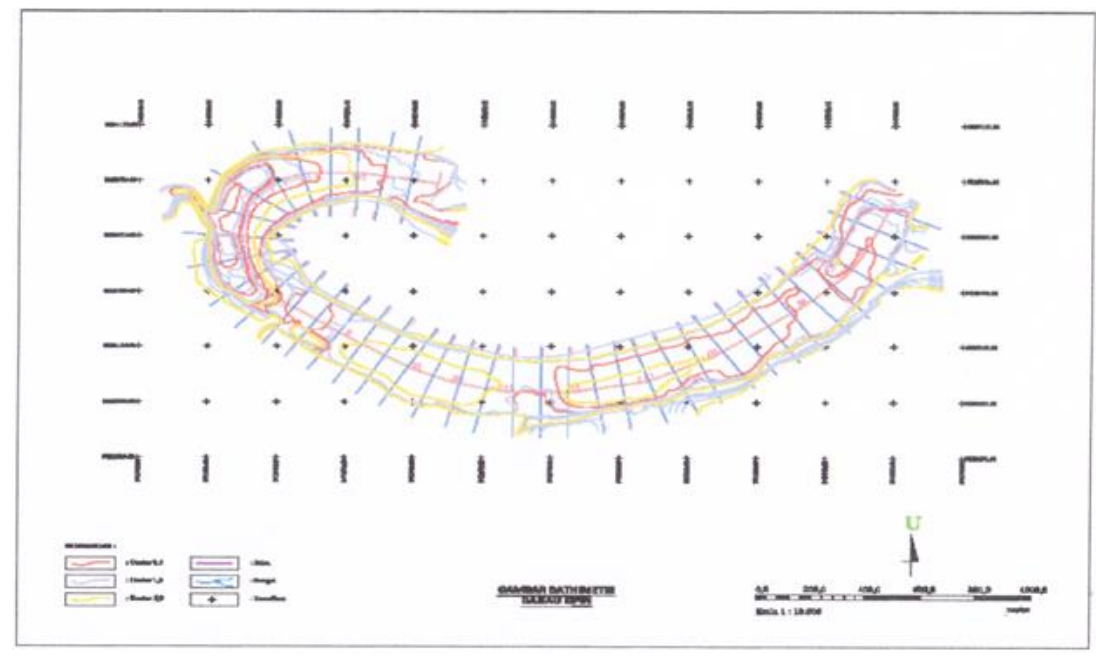

Sumber: Data olahan, 2019

Gambar 4. Kontur Topografi Danau Sipin 
Intensitas Curah Hujan

Intensitas curah hujan adalah tinggi atau kedalaman air hujan persatuan waktu.

Tabel 3. Perhitungan Analisa Intensitas Curah Hujan

\begin{tabular}{|c|c|c|c|c|c|c|c|c|}
\hline \multirow{2}{*}{ No. } & \multirow{2}{*}{$\mathrm{T}$ (menit) } & \multirow{2}{*}{$\mathrm{t}(\mathrm{jam})$} & \multicolumn{6}{|c|}{$\mathrm{I}(\mathrm{mm} / \mathrm{jam})$} \\
\hline & & & $\mathrm{R}_{2}$ & $\mathrm{R}_{5}$ & $\mathrm{R}_{10}$ & $\mathrm{R}_{20}$ & $\mathrm{R}_{50}$ & $\mathrm{R}_{100}$ \\
\hline 1 & 5 & 0,083 & 605,789 & 660,118 & 679,930 & 690,108 & 702,323 & 707,109 \\
\hline 2 & 10 & 0,167 & 381,623 & 415,848 & 428,329 & 434,741 & 442,435 & 445,451 \\
\hline 3 & 20 & 0,333 & 240,407 & 261,968 & 269,831 & 273,869 & 278,717 & 280,616 \\
\hline 4 & 30 & 0,500 & 183,465 & 199,919 & 205,919 & 209,001 & 212,701 & 214,150 \\
\hline 5 & 40 & 0,667 & 151,447 & 165,029 & 169,983 & 172,527 & 175,581 & 176,777 \\
\hline 6 & 50 & 0,883 & 130,513 & 142,218 & 146,487 & 148,679 & 151,331 & 152,342 \\
\hline 7 & 60 & 1,000 & 115,576 & 125,941 & 129,721 & 131,663 & 133,993 & 134,906 \\
\hline 8 & 70 & 1,167 & 104,288 & 113,641 & 117,052 & 118,804 & 120,907 & 121,731 \\
\hline 9 & 80 & 1,333 & 95,406 & 103,962 & 107,082 & 108,685 & 110,609 & 111,363 \\
\hline 11 & 100 & 1,667 & 82,218 & 89,592 & 92,281 & 93,662 & 95,320 & 95,969 \\
\hline 13 & 120 & 2,000 & 72,808 & 79,338 & 81,719 & 82,942 & 84,410 & 84,986 \\
\hline 14 & 130 & 2,167 & 69,025 & 75,215 & 77,473 & 78,632 & 80,024 & 80,569 \\
\hline 15 & 140 & 2,333 & 65,698 & 71,590 & 73,738 & 74,842 & 76,167 & 76,686 \\
\hline 16 & 150 & 2,500 & 62,744 & 68,371 & 70,423 & 71,477 & 72,743 & 73,238 \\
\hline 17 & 160 & 2,667 & 60,102 & 65,492 & 67,458 & 68,467 & 69,679 & 70,154 \\
\hline 18 & 170 & 2,833 & 57,721 & 62,898 & 64,786 & 65,755 & 66,919 & 67,375 \\
\hline 19 & 180 & 3,000 & 55,563 & 60,546 & 62,363 & 63,297 & 64,417 & 64,856 \\
\hline
\end{tabular}

Sumber: Hasil perhitungan, 2019

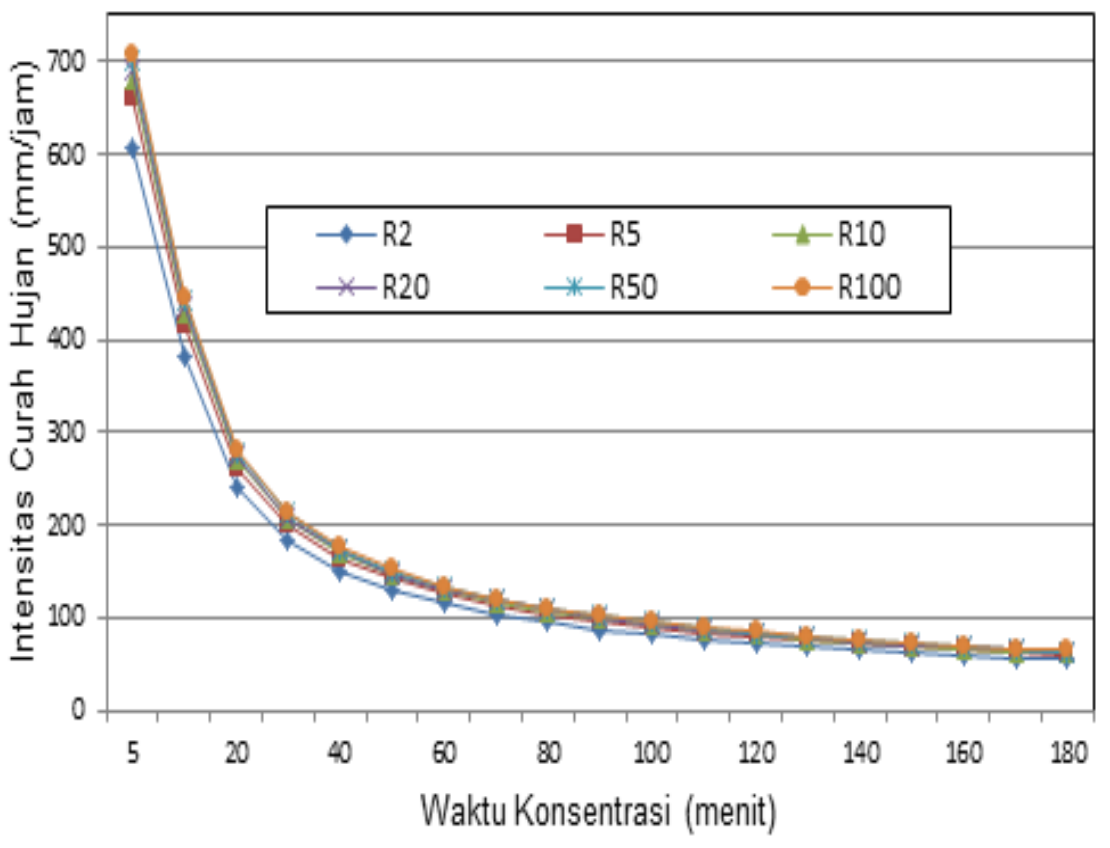

Sumber : Data Olahan, 2019

Gambar 5. Intensitas Curah Hujan

\section{Debit Rencana}

Perhitungan debit rencana dilakukan dengan menggunakan metode Rasional. sebagai berikut :

$\mathrm{Q}_{\mathrm{P}}=0,278 \times \mathrm{C} \times \mathrm{I} \times \mathrm{A}$

Dimana $\mathrm{C}$ adalah nilai Koefisien pengaliran yaitu 0,75, dan I adalah Intensitas hujan dalam periode ulang hujan (T) 20 tahun, yaitu $379,781 \mathrm{~mm}$ dan A yaitu $11.749 .320 \mathrm{~m}^{2}\left(11,749 \mathrm{~km}^{2}\right)$.

Maka:

$\mathrm{QP}_{\mathrm{P}} \quad=0,278 \times \mathrm{C} \times \mathrm{I} \times \mathrm{A}$

$Q_{\mathrm{P}} \quad=0,278 \times 0,75 \times 379,781 \times 11,749=\mathbf{9 3 0 , 3 3 7} \mathrm{m}^{3} / \mathrm{dtk}$

Berikut ini ditampilkan Perhitungan Rekapitulasi Kapasitas Tampungan dan Genangan berdasarkan beda Kontur . 
Tabel 4. Rekapitulasi Kapasitas Tampungan Luas Genangan Danau Sipin

\begin{tabular}{cccccc}
\hline No & Elevasi & $\begin{array}{c}\text { Beda Tinggi } \\
(\mathbf{m})\end{array}$ & $\begin{array}{c}\text { Luasan } \\
\left(\mathbf{m}^{\mathbf{2}}\right)\end{array}$ & $\begin{array}{c}\text { Volume } \\
\left(\mathbf{m}^{\mathbf{3}}\right)\end{array}$ & $\begin{array}{c}\text { Vol. Komulatif } \\
\left(\mathbf{m}^{\mathbf{3}}\right)\end{array}$ \\
\hline 1 & 11,81 & - & - & - & - \\
2 & 12,00 & 0,19 & $4.064,58$ & 382,07 & 382,07 \\
3 & 12,50 & 0,50 & $17.634,46$ & $5.424,76$ & $5.806,83$ \\
4 & 13,00 & 0,50 & $45.574,57$ & $15.802,26$ & $21.609,09$ \\
5 & 13,50 & 0,50 & $63.109,42$ & $27.171,00$ & $48.780,09$ \\
6 & 14,00 & 0,50 & $87.458,51$ & $37.641,98$ & $86.422,07$ \\
7 & 14,50 & 0,50 & $115.626,07$ & $50.771,14$ & $137.193,21$ \\
8 & 15,00 & 0,50 & $290.846,37$ & $101.618,11$ & $238.811,32$ \\
9 & 15,50 & 0,50 & $408.538,33$ & $174.846,17$ & $413.657,50$ \\
10 & 16,00 & 0,50 & $780.961,30$ & $297.374,91$ & $711.032,41$ \\
11 & 16,50 & 0,50 & $901.316,47$ & $420.569,44$ & $1.131 .601,85$ \\
12 & 17,00 & 0,50 & $1.000 .932,97$ & $475.562,36$ & $1.607 .164,21$ \\
13 & 17,50 & 0,50 & $1.049 .636,32$ & $512.642,32$ & $2.119 .806,53$ \\
14 & 18,00 & 0,50 & $1.089 .636,32$ & $534.818,16$ & $2.654 .624,69$ \\
15 & 18,50 & 0,50 & $1.119 .636,32$ & $552.318,16$ & $3.206 .942,85$ \\
16 & 19,00 & 0,50 & $1.139 .636,32$ & $564.818,16$ & $3.771 .761,01$ \\
\hline
\end{tabular}

Sumber: Data Olahan, 2019

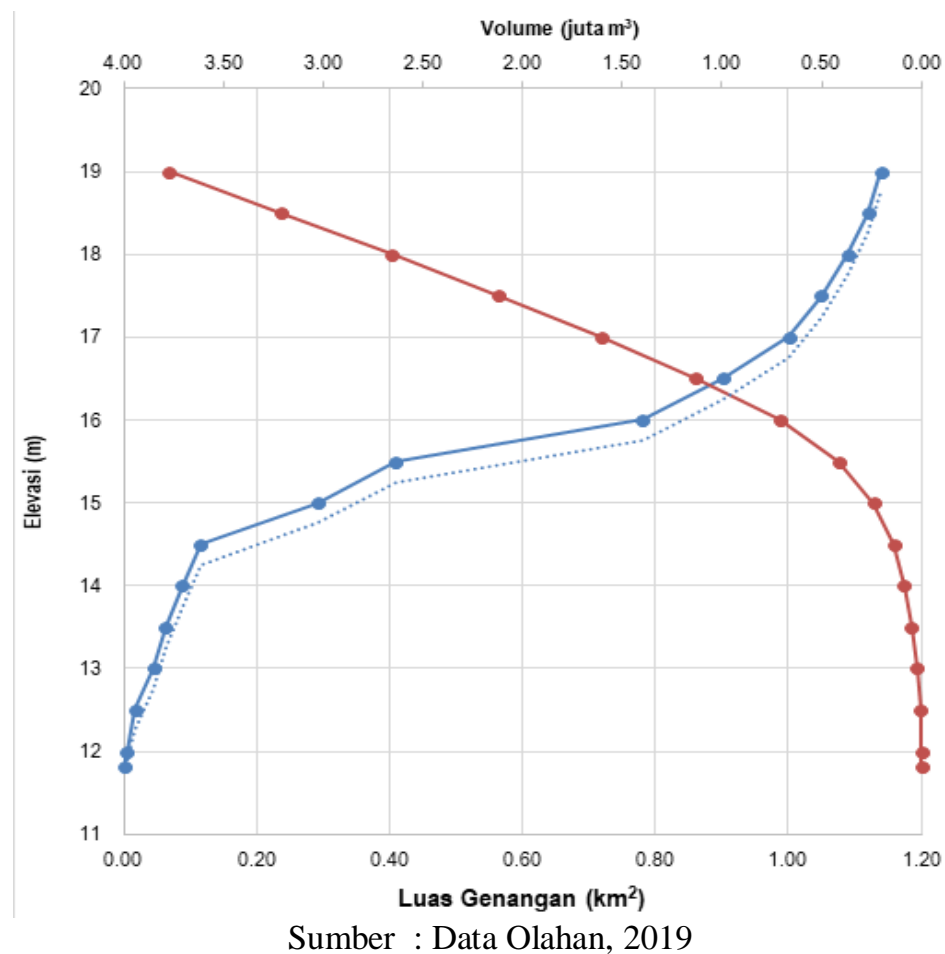

Gambar 6. Lengkung Kapasitas Tampungan dan Genangan

\section{SIMPULAN}

1. Setiap kenaikan lengkung Elevasi, maka semakin besar Volume Tampungan Danau Sipin.

2. Kenaikan Debit sungai yang masuk ke Danau sipin karena hujan akan mempengaruhi Volume Tampungan, walaupun sudah ada pintu pengatur debit aliran sungai yang masuk.

3. Berdasarkan analisis data di peroleh luas Cathment Area Danau Sipin yang berada di Sungai Kambang $6.892 .791,1 \mathrm{~m} 2$ dan yang berada pada di Sungai Putri $\pm 4.856 .529,1 \mathrm{~m} 2$,sehingga jumlah Luasnya 11.749.320,6 m 2.

4. Pemanfaatan Danau Sipin sangat selain menampung Air Hujan sebagai penangkap banjir juga bermanfaat bagi masyarakat Kota Jambi sebagai rekreasi masyakat khususnya warga Kota Jambi dan bagi Penduduk yang tinggal di daerah sekitarnya sebagai mata pencarian mencari ikan dan berternak ikan dengan membuta Keramba .

\section{DAFTAR PUSTAKA}

Asdak, Chay. 2010. Hidrologi dan Pengelolaan Daerah Aliran Sungai. Yogyakarta: Gajah mada University Press.

Barus, T. A. 2004. Pengantar Limnologi Studi Tentang Ekosistem Sungai dan Danau, Departemen Biologi Fakultas MIPA USU, Medan: USU Press. 
Effendi, H. 2003. Telaah Kualitas Air. Kanisius. Yogyakarta.

Kamia, I Made. 2011, Teknik Perhitungan Debit Rencana Bangunan Air. Grahallmu. Yogyakarta.

Sihotang, C. dan Efawani. 2006. Penuntun Praktikum Limnologi. Fakultas Perikanan Dan Ilmu Kelautan UNRI : Pekanbaru.26 hal.

Odum, E. P. (1994). Dasar - Dasar Ekologi. Edisi Ketiga. Terjemahan T. Samingan. Yogyakarta: Universitas Gadjah Mada Press.

Wilson, E. M., 1993. Hidrologi Teknik. Penerbit ITB, Bandung. 